HERBERT E. HUPPERT

Department of Applied Mathematics

and Theoretical Physics,

Cambridge University,

Cambridge CB3 9EW, UK

R. STEPHEN J. SPARKS

Department of Earth Sciences,

Cambridge University,

Cambridge CB2 3EQ, UK

NICHOLAS T. ARNDT

Max-Planck-Institut für Chemie,

Saarstrasse 23, Postfach 3060 ,

D-6500 Mainz, FRG

1. Huppert, H. E., Sparks, R. S. J., Turner, J. S. \& Arndt, N. T. Nature 309, 19-22 (1984)

2. Naldrett, A. J. Can. Inst. Min. Metall. Bull. 66, 45-63 (1973).

3. Naldrett, A. J. Econ. Geol. 75th Anniversary Volume, 628685 (1981).

4. Gresham, J. J. Miner. Deposito (in the press).

5. Coad, P. R. Ontario Geol. Surv. Study 20, (1979).

6. Lesher, C. M., Arndt, N. T. \& Groves, D. I. Sulphide Deposits in Mafic and Ultramafic Rocks (eds Buchanan, D. L. \& Jones, M. J.) 70-80 (IMM, London, 1983).

7. Nesbitt, R. W. \& Sun, S. S. Earth planet. Sci. Lett. 31, 433-453 (1976).

8. Sun, S. S. \& Nesbitt, R. W. Contr. Miner. Petrol. 65, 301-325 (1978).

9. Arndt, N. T. \& Nesbitt, R. W. in Komatiites (eds Arndt, N. T. \& Nesbitt, R. W.) 309-330 (Allen \& Unwin, London, 1982).

10. Claoué-Long, J. C., Thirwall, M. F. \& Nesbitt, R. W. Nature 307, 697-701 (1984)

11. Bickle, M. J. Nature 312, 702-703 (1984)

12. Huppert, H. E. \& Sparks, R. S. J. J. Petrol. (in the press).

\section{Cyclic GMP and neurone death}

THE recent report by Weill and Greene', indicating that the daily treatment of chick embryos with dibutyryl cyclic GMP during the period of naturally occurring motoneurone death prevents much of this normal cell loss, is of considerable interest. For, if correct, this observation advances the analysis of neurone death by bringing us one step closer to understanding the cellular and molecular events involved. However, for reasons described below, I wish to provide a note of caution to those who, on the basis of this report, may intend to pursue this line of investigation.

In a review paper on neurone death published a few years ago, I suggested that cyclic GMP might be involved in the regulation of this developmental phenomenon $^{2}$. In fact, at that time a graduate student in my laboratory was investigating this problem ${ }^{3}$. Although his experiments were generally similar to those of Weill and Greene, he failed consistently to find any effect of cyclic nucleotides, including dibutyryl cyclic GMP, on neurone death. At about the same time, I was contacted by $\mathrm{Dr}$ Weill and asked to review a manuscript she was considering submitting for publication; this paper transpired to be virtually the same as that published later in Nature. On reading the paper, and through additional correspondence and conversations, I learned that there were a few procedural differences between our experiments and those of Weill and Greene: for example, although our experiments used several different doses of dibutyryl cyclic GMP, extending over a range of three log units, the highest dose was slightly lower than the single dose used by Weill and Greene (that is, $0.91 \mathrm{mg}$ ). Consequently, since that time we have conducted four additional independent and virtually exact replicates of the Weill and Greene experiments, including the use of dibutyryl cyclic GMP from the same manufacturer's lot (Sigma, St Louis) and at the same dosage. In all four experiments the results were the same: dibutyryl cyclic GMP had no effect on motoneurone survival (day 10 controls $=12,192 \pm 809$, $n=12$; day 10 experimentals $=12,356 \pm$ $937, n=18$ ). We also failed to observe any differences in the number of nucleoli in the motoneurones of treated embryos, contrary to the report of Weill and Greene.

As the specific strain of chicken eggs used in the two laboratories differed, it is possible that genetic factors are at issue here. I believe, however, that this is highly unlikely: first, the four attempts by us to replicate the results of Weill and Greene fortuitously involved four different strains, including both 'egg' and 'broiler' types; second, we have never observed previously such all-or-none strain differences in a series of related pharmacological studies on neurone death ${ }^{4}$. Thus, in an extensive attempt to meticulously replicate the experiments of Weill and Greene, I have not been able to confirm their claim that dibutyryl cyclic GMP affects motoneurone survival.

\section{RONALD W. OPPENHEIM}

Department of Anatomy,

Wake Forest University,

Bowman Gray School of Medicine,

Winston-Salem,

North Carolina 27103, USA

1. Weill, C. L. \& Greene, D. P. Nature 308, 452-454 (1984). 2. Oppenheim, R. W. in Studies in Developmentel Neurobiology, Essays in Honor of Viktor Hamburger (ed. Cowan, W. M.) 74-133 (Oxford University Press, 1981). . Jones, R. O. thesis, North Carolina Central Univ. (1982). 4. Oppenheim, R. W. \& Chu-Wang, I-W. in Somatic and Autonomic Nerve-Muscle Interactions (ed. Burnstock, G.) 57-107 (Elsevier, Amsterdam, 1983).

WEILL REPLIES-Our initial experiments in which we injected dibutyryl cyclic GMP into developing chick embryos were carried out using a crossed strain of chicken eggs (Harco $\times$ Partner). We found that a daily dose of $0.91 \mathrm{mg}$ of dibutyryl cyclic GMP effected a $58 \%$ increase in the number of surviving lateral motor column motoneurones. Owing to the novelty of the observation, I contacted Dr Oppenheim and several other senior workers in the field and, at their collective suggestion, extended our original observations to include many more embryos. The results of this work were those published'.

Subse uent attempts to repeat this experiment using White Leghorn embryos (Truslow Farms, Chestertown, Maryland) at the same dose level of dibutyryl cyclic GMP failed to increase the level of motoneurone survival. Further experimentation has revealed that daily injections of $0.864 \mathrm{mg}$ of dibutyryl cyclic GMP. $2 \mathrm{H}_{2} \mathrm{O}$ effects the survival of $53.5 \%$ of those cells that would have died by embryonic day 10 (day 10 controls = $14,390 \pm 439, n=12$; day 10 dibutyryl cyclic GMP-treated $=17,950 \pm 376, \quad n=8$, mean \pm s.e.m.). The dose-response curve is biphasic and the range of effective doses uncommonly narrow, as variations in dose of $\pm 5 \%$ do not give a positive response. We observed no increase in the number of cells with two or more nucleoli in the White Leghorns, unlike the effect on the red strain. We have no explanation for the apparent difference in the response of the two strains. These experiments are nearing completion and a manuscript is in preparation.

Our interpretation of the results observed with the crossed red strain of embryos stemmed from our other published work ${ }^{2}$, which demonstrated an increase in neuronal cyclic GMP levels over embryonic days $5-10$ in the absence of a change in the cyclic GMP level of leg muscle over the same time period. An increase in neuronal cyclic GMP levels was also observed for spinal cord neurones co-cultured with muscle factors. We concluded that muscle factor(s) could cause an increase in neuronal cyclic GMP levels over the period of natural motoneurone cell death. We then wondered whether increased intraneuronal concentrations of cyclic GMP would enhance motoneurone survival by mimicking the presence of the appropriate muscle factors. Our interpretation of the results obtained is that dibutyryl cyclic GMP increases the neuronal levels of cyclic GMP and, via an as yet undetermined mechanism(s), effects an increase in motoneurone survival.

It was not our intention to slight the extensive contributions that Dr Oppenheim had made to this field by not including a discussion of our results in the context of his proposed model ${ }^{3}$, which involves intramuscular cyclic GMP levels. We had data demonstrating that levels of cyclic GMP in muscle did not change during natural motoneurone cell death, whereas intraneuronal cyclic GMP levels did increase during natural cell death ${ }^{2}$. A discussion of the intramuscular cyclic GMP model did not seem germane to our conclusions. We are, in fact, indebted to Dr Oppenheim and his colleagues, for it is their work in part that has formed the basis for our own investigations.

Note added in proof: Meriney et al. ${ }^{4}$ have reported the prevention of ciliary ganglion cell death by cyclic GMP.

Departments of Neurology

Cheryl L. WeILl and Anatomy.

Louisiana State University Medical Center, New Orleans, Louisiana 70112, USA

1. Weill, C. L. \& Greene, D. P. Nature 308, 452-454 (1984) 2. Weill, C. L. Neurosci. Lett. 30, 263-268 (1982).

3. Oppenheim $\mathrm{R}$ W in Studies in Developmental Neurobiology, Essays in Honoor of Viksor Hamburger (ed. Cowrobiology, W. M.) 74-133 (Oxford University Press, 1981). 4. Meriney et al. Neurosci. Abs. 10,640 (1984). 